\title{
CUSTOMER PERCEPTION, SATISFACTION AND BEHAVIOURAL INTENTIONS TOWARDS HOSPITAL MEAL SERVICES IN GOVERNMENT AND PRIVATE HOSPITALS IN ALOR SETAR, KEDAH
}

\author{
NORSYAZANA ZAKARIA AND ABDUL WAHAB*
}

Faculty of Fisheries and Food Science, University Malaysia Terengganu, Kuala Terengganu, Malaysia.

*Corresponding author: rahijan@umt.edu.my

http://doi.org/10.46754/umtjur.2021.07.2020

\begin{abstract}
There are two types of hospital in general, which are government and private hospitals. This study will help us to understand the customer perception, satisfaction and behavioural intention of hospital meal services in both government and private hospitals in Alor Setar, Kedah. Private and government hospitals differ in their style of food offering and service system. From this, customer perception, satisfaction, and behavioural intentions were investigated using a questionnaire survey with 150 respondents using descriptive and inferential analysis. The study shows that between government and private hospitals in Alor Setar, Kedah, the respondents show a positive perception of hospital meal services in Alor Setar in both government and private hospitals. In terms of customer satisfaction, both types of hospital show high satisfaction from all respondents. However, private hospital scores a bit higher in terms of satisfaction since the services and facilities are more upgraded than those of the government hospital of which respondents did not have such a high expectation for satisfaction since the fee is much lower than the private hospital. In the comparison of hospital meal services in terms of socio-demographic profile, there is no significant difference in gender and education level in both types of hospital. However, age and income level show a significant level of $\mathrm{p}=0.011$ in age for a government hospital and $\mathrm{p}=0.018$ and $\mathrm{p}=0.020$ in monthly income for a private hospital. For the relationship of all variables (customer perception, satisfaction and behavioural intention), all of those show a robust, lively and direct relationship with each other. Hence, this study can help public and private hospitals improve their meal services and image to attract more customers.
\end{abstract}

Keywords: Customer perception, satisfaction, behavioural intention, hospital meal services

\section{Introduction}

The health care industry is growing year by year: either the private or public hospital or solely operated Hospital. In 2016, there were around 153 public hospitals and 216 private hospitals in Malaysia (Statista, 2018). Healthcare industries are also moving forward with many new ideas to improve their services itself and moving towards a new direction, such as putting more awareness on the wellness of dietary choices in hospital food service (Lee, 2013). The patients' satisfaction has become a fundamental criterion by which the quality of the health services itself can evaluate (Amany et al., 2012). The patients in and visitors of the hospital seem to be significantly attracted to learn more about what they eat, the calories of the food, the quality of food they order in the hospital and the feel of the overall experience of the hospital food (Lee, 2013). The quality of the meal should be maintained and improved. The hospital can use one of the initiatives in improving their meal and service quality by creating the call centreroom services and personalized room-services. Sometimes, the personal touch that the hospital gives to their customers can bring a lot of change in hospital image and quality of services (Lee, 2013). After the enhancement is made, the hospital can increase the number of patients, improve the hospital image and optimize the hospital services to meet the patients' needs. 
Besides, the government and private hospitals can use the data on this apparent assessment, patient satisfaction and behavioural intention and take into consideration when they want to make changes to their meal services. In terms of their behavioural intention, the patients will likely foods. Nowadays, people are becoming more aware of their health since many diseases can occur even at an early age. Since the hospital can provide an excellent place for them to keep their healthy lifestyle, the probability for them to revisit it is high and thus attracting other people to want an experience similar to what regular customers have put a value on.-

Moreover, there is also pressure on foodservice operators to meet higher nutritional standards to keep patients healthier and reduce the risk of readmission, as well as giving patients a good taste of the food (Becker, 2015). There is also a lack of study on government and private hospital meal services. By studying patient satisfaction towards the hospital meal services between both private and government hospitals, the information gathered can be used to improve the services in terms meal and services provided by the hospital.

The objective of this study is to determine customer perception and behavioural intentions towards hospital meal services provided by hospitals in Alor Setar, to determine the level of customer satisfaction towards hospital meal services between private and government hospital ins Alor Setar, to compare on hospital meal services between private and hospital meal services in Alor Setar, Kedah based on socio-demographic background and to study on the relationship between customer perception, satisfaction and behavioural intentions towards hospital meal services.

People will make a choice between private and government hospitals based on their financial situation, their health state, perception of the services provided between those two and also the availability of the hospital in the neighbourhood. By studying patient satisfaction towards the hospital meal services by both private and government hospitals, the information gathered can be used to improve the hospital services in terms of hospital services and meals provided. The perception of people can also be changed to a better view. Moreover, its been said that the quality of food services affects patient satisfaction with hospital stay. In this study the hospital can increase the quality of meal and services provided and improve meal conditions of the patients and caregivers (Becker, 2015). Both types of hospital can take this study data as one of their references when constructing or renewing their meal services system.

By studying the apparent assessment, customer satisfaction and behavioural intentions of the hospital meal services in private and government hospital can help the Ministry of Health to increase their data on patients' view on hospital meal services system and improve the healthcare industry.

\section{Materials and Methods}

\section{Data collection process}

The main criteria for the sample selection were the ability of the customer on evaluating food service quality. The respondents who agreed to participate in the study were included in the sample. The questionnaire given was selfadministered. There were about 150 respondents in this survey. For the data collection, a selection of hospitals around Alor Setar had been made, which were Hospital Sultanah Bahiyah, Putra Medical Centre and KPJ HealthCare Alor Setar. The objective of the study was explained to the selected respondents before the questionnaire was distributed. Help was given with any explanation needed and the researchers waited for the questionnaire to be answered. Then, the data collected f were kept in and run using SPSS software 20 .

\section{Questionnaire structure}

The structured questionnaire was divided into four major parts. Section A deals with the respondent's demographic profile such as gender, ethnicity, age, education level, monthly income 
and marital status. A descriptive questionnaire is related to targeted respondents such as type of hospital stay, time spent in the hospital and current diet. Section B comprises of items relating to independent variables which focus on the three attributes of customer perception of private and government hospital meal services consisting of food and beverage quality, service quality and quality of facilities. Section $\mathrm{C}$ is used to measure customer satisfaction as the mediating variables. Section D measures the customer behavioural intention as the dependent variable. Respondents were required to translate their view on a five-point Likert scale ranging from 1 with "strongly disagree to 5 "strongly agree".

\section{Results and Discussion}

\section{Socio-demographic profile}

Table 1: Frequency and percentage of socio-demographic section

\begin{tabular}{|c|c|c|c|}
\hline \multicolumn{4}{|c|}{$\mathrm{n}=150$} \\
\hline Demographic background & & Frequency & $\%$ \\
\hline \multirow[t]{2}{*}{ Gender } & Male & 56 & 37.3 \\
\hline & Female & 94 & 62.7 \\
\hline \multirow[t]{3}{*}{ Ethnicity } & Malay & 90 & 60.0 \\
\hline & Chinese & 35 & 23.3 \\
\hline & Indian & 25 & 16.7 \\
\hline Citizenship & Malaysian & 150 & 100 \\
\hline \multirow[t]{5}{*}{ Age } & $18-25$ & 79 & 52.7 \\
\hline & $26-35$ & 18 & 12.0 \\
\hline & $36-45$ & 13 & 8.7 \\
\hline & $46-55$ & 20 & 13.3 \\
\hline & Above 55 & 20 & 13.3 \\
\hline \multirow[t]{6}{*}{ Education level } & SPM & 49 & 32.7 \\
\hline & STPM & 4 & 2.7 \\
\hline & Diploma & 26 & 17.3 \\
\hline & Degree & 60 & 40.0 \\
\hline & Master & 1 & 0.7 \\
\hline & Others & 10 & 6.7 \\
\hline \multirow[t]{3}{*}{ Marital status } & Single & 90 & 60.0 \\
\hline & Married & 58 & 38.7 \\
\hline & Divorced & 2 & 1.3 \\
\hline \multirow[t]{6}{*}{ Monthly income } & Less than RM 1500 & 122 & 81.3 \\
\hline & RM 1500 - RM 2999 & 13 & 8.7 \\
\hline & RM 3000 - RM 3999 & 10 & 6.7 \\
\hline & RM 4000 - RM 4999 & 1 & 0.7 \\
\hline & RM 5000 - RM 5999 & 2 & 1.3 \\
\hline & RM 6000 above & 2 & 1.3 \\
\hline
\end{tabular}




\begin{tabular}{cccc}
\hline Have you tasted hospital & Yes & 150 & 100 \\
food? & No & 0 & 0 \\
In what capacity did you & Staff & 6 & 4.0 \\
taste the hospital food? & Patient & 67 & 44.7 \\
& Visitor & 76 & 50.7 \\
Hospital type & Others & 1 & 0.7 \\
& Government & 75 & 50.0 \\
Where in the hospital, & Private & 75 & 50.0 \\
hid you taste the & Cafeteria & 64 & 42.7 \\
hospital food? & Patient Ward & 85 & 56.7 \\
\hline
\end{tabular}

From the table, it shows that out of 150 respondents, 56 are male and 94 are female respondents. In terms of race, $60 \%$ are Malays, $35 \%$ are Chinese and $25 \%$ are Indians. All of the respondents are Malaysians living in Alor Setar, Kedah. In terms of age, $52.7 \%$ are people in the 18 to 25 -year age group. It is an age where there are a lot of school and university students here and some that had working for a few years. People in the range of 46 to 55 years of age and 55 years old and above are the second largest in this research with $13.3 \%$ for both age groups. People in the age group 26 to 35 years old and those between 36 to 45 years old contribute about $12 \%$ and $8.7 \%$ respectively. Based on the data, the respondents came from diverse age groups. However, the number of young people was high due to their high distribution in the survey area.

From the education level, $40 \%$ comes from degree holders, $32.7 \%$ from SPM holders, and 17.3 from diploma holders and the rest were from STPM, Master and others with $2.7 \%, 0.7 \%$ and $6.7 \%$ respectively. Others include education at primary school, SRP (Sijil Rendah Pelajaran)@
LCE (Lower Certificate of Education) levels, skill certificate level, and those who did not finish school or did not go to school at all. In terms of marital status, $60 \%$ of respondents were single, $38.7 \%$ were married and $1.3 \%$ were divorced. Based on monthly income data from respondents, about $81.3 \%$ of respondents had monthly income less than RM 1500, 8.7\% from income within RM 1500 to RM 2999, 6.7\% from RM 3000 to RM 3999 and the rest are RM 4000 to RM 4999 (0.7\%), RM 5000-RM 5999 $(1.3 \%)$ and RM 6000 and above (1.3\%). The average of monthly income for Kedah is lowest, from RM 999 to highest RM 3811 (Malaysia HIBAS, 2018).

All of the respondent had tasted hospital food either as patients $(44.7 \%)$, hospital staff $(4.0 \%)$ or visitors $(50.7 \%)$ and others $(0.7 \%)$. The respondents had tasted the hospital food either in the cafeteria, as patients or both with $42.7 \%, 56.7 \%$ and $0.7 \%$ respectively. The percentage of respondents who had tasted the hospital food is balanced with 75 respondents for each type of hospital. 
To determine the customer perception, satisfaction and behavioural intention on hospital meal and services provided by private and government hospitals in Alor Setar

Section B: Customer perception

Table 2: Median and IQR of Section B (Customer Perception)

\begin{tabular}{|c|c|c|}
\hline \multirow[t]{2}{*}{ Customer perception } & Government hospital & Private hospital \\
\hline & Median (IQR) & Median (IQR) \\
\hline $\begin{array}{l}\text { Liking hospital meal services in } \\
\text { general }\end{array}$ & $4(1)$ & $4(0)$ \\
\hline Good food presentation & $4(1)$ & $4(1)$ \\
\hline Food arrived on time. & $4(1)$ & $4(1)$ \\
\hline $\begin{array}{l}\text { Thought that hospital food here } \\
\text { was good }\end{array}$ & $4(1)$ & $4(0)$ \\
\hline $\begin{array}{l}\text { Thought that food was high in } \\
\text { calories }\end{array}$ & $3(1)$ & $3(1)$ \\
\hline $\begin{array}{l}\text { Thought that food served provided } \\
\text { nutrition to improve health }\end{array}$ & $4(1)$ & $4(2)$ \\
\hline The food suited customer taste & $4(1)$ & $4(2)$ \\
\hline Quantity of food was sufficient. & $4(0)$ & $4(1)$ \\
\hline The food was properly cooked. & $4(0)$ & $4(1)$ \\
\hline Hot food served hot & $4(1)$ & $4(1)$ \\
\hline Cold food served cold & $4(1)$ & $4(1)$ \\
\hline The food looked appetizing & $4(1)$ & $4(1)$ \\
\hline Common food always served & $3(1)$ & $2(2)$ \\
\hline $\begin{array}{l}\text { Thought that all hospital food is } \\
\text { the same }\end{array}$ & $3(2)$ & $3(2)$ \\
\hline The food smelt nice & $4(1)$ & $4(2)$ \\
\hline Cleanliness of fork and spoon & $4(1)$ & $4(1)$ \\
\hline First impression on hospital food & $4(1)$ & $4(0)$ \\
\hline $\begin{array}{l}\text { The food was not bland as } \\
\text { customers thought }\end{array}$ & $4(1)$ & $4(1)$ \\
\hline Food portion was too much. & $2(1)$ & $2(1)$ \\
\hline Beverages were too sweet. & $2(1)$ & $2(1)$ \\
\hline Beverages were good. & $4(0)$ & $4(0)$ \\
\hline $\begin{array}{l}\text { Staff did a good job preparing the } \\
\text { food }\end{array}$ & $4(1)$ & $4(1)$ \\
\hline No variety of food served & $3(2)$ & $2(2)$ \\
\hline Variety of food served & $4(1)$ & $4(1)$ \\
\hline
\end{tabular}

*median is based on 5-point Likert Scale (1 strongly disagree to 5 strongly agree) 
In Section B, which is customer perception, there were 24 questions on customer perception on hospital meal services. The study examines that almost all the questions regarding perception of hospital meal services in both government and private hospitals score in median 4 while for the median 3 only indicates that the customers neither agree or disagree that the hospital food was high in calories and had common hospital food (Zahid et al., 2015). From the data, it can be said that almost all respondents had a positive view on hospital food regardless of the type of hospital they stayed and stated that their hospital food was not high in calories and there was a variety of hospital food meaning that they were not served with the same food repeatedly.

For median 2, the customers disagreed that the food has no variety and beverages served were too sweet. This concludes that the hospital food that were served had a variety and the beverages is were not too sweet. The reasons that almost all respondents were positive on hospital food may be because of the way the food was served, food temperature, appearance and aroma of the food were all nice.

\section{Section C: Customer satisfaction}

Table 3: Median and IQR of Section C (Customer Satisfaction)

\begin{tabular}{lcc}
\hline \multicolumn{1}{c}{ Customer satisfaction } & Government hospital & Private hospital \\
\cline { 2 - 3 } & Median (IQR) & Median (IQR) \\
\hline Satisfied with the food provided & $4(1)$ & $4(0)$ \\
Satisfied with hospital services & $4(0)$ & $4(0)$ \\
Satisfied with facilities provided & $4(0)$ & $4(0)$ \\
Overall satisfaction with meal and services & $4(1)$ & $4(1)$ \\
Staff delivered food correctly & $4(1)$ & $4(0)$ \\
Friendly staff & $4(1)$ & $4(0)$ \\
Liking hospital food & $4(1)$ & $4(0)$ \\
\hline
\end{tabular}

*median is based on 5-point Likert Scale (1 strongly disagree to 5 strongly agree)

The data for both government and private hospitals, show that the customer gave a high score for satisfaction. However, the private hospital scored a bit more in terms of satisfaction due to their more upgraded services and facilities. Moreover, patients and their relatives came to the hospital expecting the facilities provided could make their stay comfortable (Mishra

\section{Section D: Behavioural intention}

Table 4. Median and IQR of Section D (Behavioural Intention)

\begin{tabular}{lcc}
\hline Behavioural intention & $\begin{array}{c}\text { Government hospital } \\
\text { Median (IQR) }\end{array}$ & $\begin{array}{c}\text { Private hospital } \\
\text { Median (IQR) }\end{array}$ \\
\hline Willing to stay for their food again & $3(2)$ & $4(1)$ \\
Willing to recommend to others & $4(1)$ & $4(0)$ \\
Will recommend if asked & $4(1)$ & $4(1)$ \\
\hline
\end{tabular}




\begin{tabular}{lll}
\hline Will spread to others & $4(1)$ & $4(0)$ \\
Willingness to share experience & $4(1)$ & $4(1)$ \\
\hline
\end{tabular}

*median is based on 5-point Likert Scale (1 strongly disagree to 5 strongly agree)

For the behavioural intention section, the willingness to recommend and by word of mouth were seen as customers would highly recommend and spread to others about the goodness of hospital food for both types of hospital. The reasons for this may be because of the customers received good care while they were admitted in the hospital influencing also in their food taste towards hospital meal services (Zahid et al., 2015). For the government hospital, the customers did not give decisive answer whether to revisit the hospital for their food again, while for private hospital, the customers were willing to revisit the hospital for their food again. Amin and Nasharuddin, 2013 stated that the perceived quality and customer satisfaction were used for exit strategy to increase loyalty among the present customers.

\section{To determine the level of customer satisfaction towards hospital meal services between private and government hospital in Alor Setar}

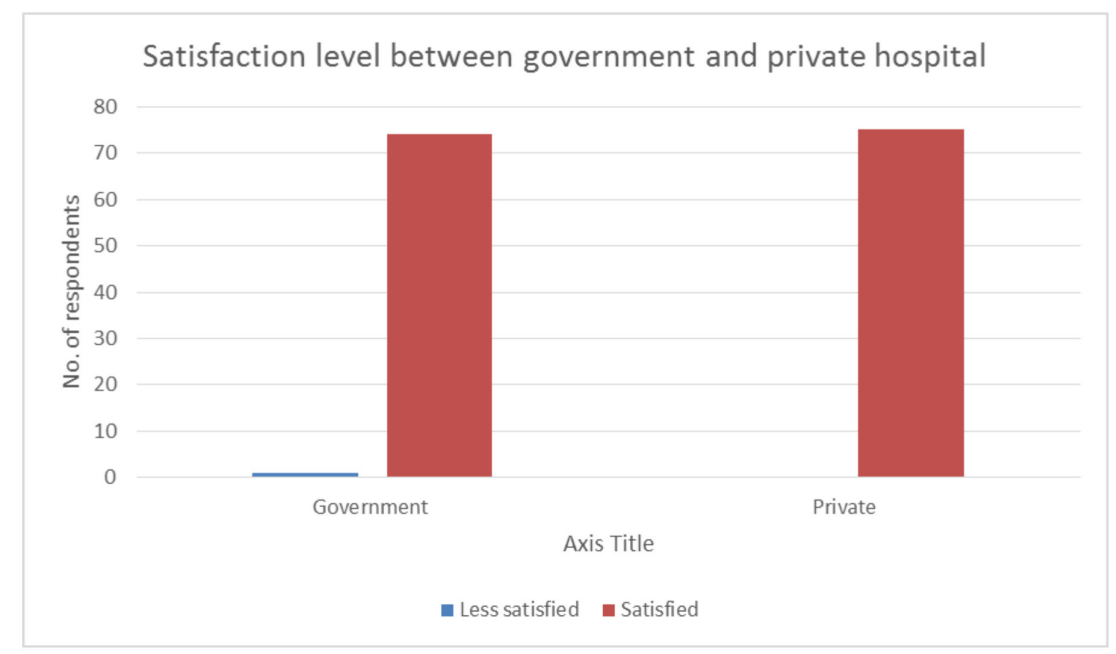

Extracted from Zahid et al., 2015.

Figure1: The satisfaction level between government and private hospitals towards hospital meal services in Alor Setar, Kedah

From the bar chart, the government hospital had 74 out of 75 respondent that are satisfied with the hospital meal services in Alor Setar while for the private hospital, 75 out of 75 respondents shown satisfaction of the hospital meal services at Alor Setar, Kedah. This customer satisfaction level was measured using Likert Scale (1 strongly disagree and 5 strongly agree). Scores less than 3 were considered less satisfied while scores of 4 and 5 were considered satisfied (Zahid et al., 2015). 


\section{Comparison of socio-demographic background with Section B, C and D}

Table 5: Comparison of gender with consumer perception, satisfaction and behavioural intention

\begin{tabular}{|c|c|c|c|c|c|}
\hline \multirow[t]{2}{*}{ Type of hospital } & $\begin{array}{c}\text { Socio- } \\
\text { demographic } \\
\text { background }\end{array}$ & & $\begin{array}{l}\text { Consumer } \\
\text { perception }\end{array}$ & $\begin{array}{l}\text { Consumer } \\
\text { satisfaction }\end{array}$ & $\begin{array}{c}\text { Behavioural } \\
\text { intention }\end{array}$ \\
\hline & \multicolumn{5}{|c|}{ p-value } \\
\hline Government & \multirow{2}{*}{ Gender } & $\begin{array}{l}\text { Male } \\
\text { Female }\end{array}$ & 0.410 & 0.523 & 0.561 \\
\hline Private & & $\begin{array}{c}\text { Male } \\
\text { Female }\end{array}$ & 0.053 & 0.091 & 0.169 \\
\hline
\end{tabular}

The survey data show that the male perception is much higher than female perception in the three variables tested which include consumer perception, satisfaction and behavioural intention. The males have been reported to have a more positive relationship in customer perception, satisfaction and behavioural intention. However, the $\mathrm{p}$-value for both gender shows that there is no significant difference of in gender in terms of customer perception, satisfaction and behavioural intention (Lee and Kim, 2017). We can assume that the null hypothesis is accepted where there is no significant difference in gender in terms of customer perception, satisfaction and behavioural intention towards hospital meal services.

Table 6: Comparison of age with consumer perception, satisfaction and behavioural intention

\begin{tabular}{|c|c|c|c|c|c|}
\hline \multirow[t]{2}{*}{ Type of hospital } & \multirow[t]{2}{*}{$\begin{array}{c}\text { Socio- } \\
\text { demographic } \\
\text { background }\end{array}$} & & \multirow{2}{*}{$\begin{array}{r}\text { Consumer } \\
\text { perception } \\
\text { p-value }\end{array}$} & \multirow[t]{2}{*}{$\begin{array}{l}\text { Consumer } \\
\text { satisfaction }\end{array}$} & \multirow[t]{2}{*}{$\begin{array}{c}\text { Behavioural } \\
\text { intention }\end{array}$} \\
\hline & & & & & \\
\hline \multirow[t]{5}{*}{ Government } & & $18-25$ & & & \\
\hline & & $26-35$ & & & \\
\hline & & $36-45$ & 0.200 & 0.011 & 0.174 \\
\hline & & $46-55$ & & & \\
\hline & 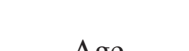 & Above 55 & & & \\
\hline \multirow[t]{5}{*}{ Private } & Age & $18-25$ & & & \\
\hline & & $26-35$ & & & \\
\hline & & $36-45$ & 0.510 & 0.839 & 0.278 \\
\hline & & $46-55$ & & & \\
\hline & & Above 55 & & & \\
\hline
\end{tabular}

In terms of age, the data show only one significant difference at 0.05 significance level $(\mathrm{p}=0.011)$ in section $\mathrm{C}$ (customer satisfaction) in the government hospital. While in other sections, there is no significant difference at all whether in private or government hospital in section B (customer perception) and section $\mathrm{D}$ (behavioural intention). This can be said that age in government hospital plays a big role in determining customer satisfaction especially for older people, according to the data collected in this study. However, a study from Lee and Kim (2017), shows no significant difference $(p>0.05)$. The study may differ based on older people's preference and location of survey being done. 
Table 7: Comparison of education level with consumer perception, satisfaction and behavioural intention

\begin{tabular}{|c|c|c|c|c|c|}
\hline \multirow[t]{2}{*}{ Type of hospital } & \multirow[t]{2}{*}{$\begin{array}{c}\text { Socio- } \\
\text { demographic } \\
\text { background }\end{array}$} & & \multirow[t]{2}{*}{$\begin{array}{l}\text { Consumer } \\
\text { perception }\end{array}$} & \multirow[t]{2}{*}{$\begin{array}{l}\text { Consumer } \\
\text { satisfaction }\end{array}$} & \multirow[t]{2}{*}{$\begin{array}{c}\text { Behavioural } \\
\text { intention }\end{array}$} \\
\hline & & & & & \\
\hline \multirow{6}{*}{ Government } & \multirow{12}{*}{ Education level } & SPM & \multirow{6}{*}{0.536} & \multirow{6}{*}{0.619} & \multirow{6}{*}{0.280} \\
\hline & & STPM & & & \\
\hline & & Diploma & & & \\
\hline & & Degree & & & \\
\hline & & Master & & & \\
\hline & & Others & & & \\
\hline \multirow{6}{*}{ Private } & & SPM & \multirow{6}{*}{0.876} & \multirow{6}{*}{0.994} & \multirow{6}{*}{0.976} \\
\hline & & STPM & & & \\
\hline & & Diploma & & & \\
\hline & & Degree & & & \\
\hline & & Master & & & \\
\hline & & Others & & & \\
\hline
\end{tabular}

The results reported that there are no significant differences between customer perception, satisfaction and behavioural intention in terms of education level for both private and government hospitals with p-value of $0.536,0.619$ and 0.280 for government and
$0.876,0.994$ and 0.976 for private hospitals at level of significance 0.05 . In contrast with Lee \& Kim, (2017), the study showed significant difference of $\mathrm{p}<0.05$ with perception and satisfaction but no significant difference in behavioural intention.

Table 8: Comparison of monthly income with consumer perception, satisfaction and behavioural intention

\begin{tabular}{|c|c|c|c|c|c|}
\hline Type of hospital & $\begin{array}{c}\text { Socio- } \\
\text { demographic } \\
\text { background }\end{array}$ & & $\begin{array}{l}\text { Consumer } \\
\text { perception } \\
\text { p-value }\end{array}$ & $\begin{array}{l}\text { Consumer } \\
\text { satisfaction }\end{array}$ & $\begin{array}{c}\text { Behavioural } \\
\text { intention }\end{array}$ \\
\hline \multirow{6}{*}{ Government } & \multirow{10}{*}{$\begin{array}{l}\text { Monthly } \\
\text { income }\end{array}$} & Less than RM 1500 & \multirow{5}{*}{0.300} & \multirow{5}{*}{0.217} & \multirow{5}{*}{0.112} \\
\hline & & RM 1500 - RM 2999 & & & \\
\hline & & RM 3000 - RM 3999 & & & \\
\hline & & RM 5000 - RM 5999 & & & \\
\hline & & RM 6000 and above & & & \\
\hline & & Less than RM 1500 & \multirow{5}{*}{0.128} & \multirow{5}{*}{0.018} & \multirow{5}{*}{0.020} \\
\hline \multirow{4}{*}{ Private } & & RM 1500 - RM 2999 & & & \\
\hline & & RM 3000 - RM 3999 & & & \\
\hline & & RM 5000 - RM 5999 & & & \\
\hline & & RM 6000 and above & & & \\
\hline
\end{tabular}


The monthly income data for the private hospital sector show a significant difference in customer satisfaction and behavioural intention with $\mathrm{p}=0.018$ and $\mathrm{p}=0.020$. The government hospital shows no significant difference in the three variables tested (customer perception, satisfaction and behavioural intention). This can be concluded that people that have high income that go to private hospital have high satisfaction and good behavioural intention, resulting in their willingness to revisit and to spread the good things about the hospital meal services to others, only if they were satisfied with the meal service.

However, the government hospital did not show any significant difference in terms of income level since almost all income groups, based on data collection come to government hospital.

\section{To study the relationship between customer perception, satisfaction and behavioural intention towards hospital meal services}

Table 9: Relationship between consumer perception, satisfaction and behavioural intention

\begin{tabular}{ccccc}
\hline & Correlation coefficient & $\begin{array}{c}\text { Customer } \\
\text { perception }\end{array}$ & $\begin{array}{c}\text { Customer } \\
\text { satisfaction }\end{array}$ & $\begin{array}{c}\text { Behavioural } \\
\text { intention }\end{array}$ \\
\cline { 2 - 5 } Spearman's rho & Customer perception & 1.00 & $0.778^{* *}$ & $0.584^{* *}$ \\
& Customer satisfaction & $0.778^{* *}$ & 1.00 & $0.731^{* *}$ \\
& Behavioural intention & $0.584^{* *}$ & $0.731^{* *}$ & 1.00 \\
\hline
\end{tabular}

**. Correlation is significant at the 0.01 level (2-tailed).

A strong, positive and direct relationship had been found to exist between customer perception with customer satisfaction and behavioural intention $\left(\mathrm{r}_{\mathrm{s}}=0.778, \mathrm{r}_{\mathrm{s}}=0.584\right.$ and $r_{s}=0.731 ; p<0.001$, two-tailed). The hypothesis that the customer perception, satisfaction and behavioural intention had a strong relationship had been confirmed by Lee and Kim (2017). The findings of the study by Amin and Nasruddin (2013) indicate that the establishment of higher levels of hospital service quality will lead customers to have a high level of satisfaction and behavioural intention. With this strong relationship, customer satisfaction can lead to subsequent behavioural intention such as revisit and positive word-of-mouth communication for this strong relationship between customer perception, satisfaction and behavioural intention, it can be said that these three variables are strongly related to study on hospital meal services between government and private hospitals in Alor Setar, Kedah.

\section{Conclusion}

As a conclusion, the study shows that in between government and private hospitals in Alor Setar, Kedah, the respondents show positive perception on hospital meal services in Alor Setar in both government and private hospitals. In terms of customer satisfaction, both types of hospital show high satisfaction from all respondents. However, private hospital scored a bit higher in terms of satisfaction since the services and facilities is are more upgraded than a government hospital in which respondents did not put such a high expectation for satisfaction since the fee is much lower than the private hospital.

In comparison of hospital meal services in terms of socio-demographic profile, there is no significant difference in gender and education level in both types of hospital. However, age and income levels show a significant level of $\mathrm{p}=0.011$ in age for government hospital and $\mathrm{p}=0.018$ and $\mathrm{p}=0.020$ in monthly income for private hospital. 
The relationship of all variables (customer perception, satisfaction and behavioural intention), show a strong, positive and direct relationship with each other.

\section{Acknowledgements}

The authors would like to thank the School of Fisheries and Food Sciences of Universiti Malaysia Terengganu for their support of this study.

\section{References}

Amany, M. A., Lina, A. Q., Reem, A. Z., Kuwair, A., Shobki, M., \& Mograbi, H. (2012). Analysis of Factors Affecting the Satisfaction Levels of Patients Towards Food Services at General Hospitals in Makkah, Saudi Arabia. American Journal of Medicine and Medical Science, 2(6), 123-130.

Amin, M. \& Nasharuddin, S. Z. (2013). Hospital service quality and its effects on patient satisfaction and behavioural intention. Clinical Governance an International Journal, 3(18), 238-254.

Becker's Hospital Review. 2015. Hospitals are hungry for changes in foodservice. Retrieved from https://www.beckershospitalreview. com.

Hassali, M. A., Alrasheedy, A. A., Ab Razak, B. A., Al-Tamimi, S. K., Saleem, F., Ul Haq, N., \& Aljadhey, H. 2014. Assessment of general public satisfaction healthcare services in Kedah, Malaysia. The Australasian medical journal, 1(7), 35-44.
Hazilah, N. A. M., .2012,'Inpatient satisfaction: an analysis of Malaysian public hospitals", International Journal of Public Sector Management, 25(1), 6-16.

Jang S.S., \& Namkung. (2009). Perceived quality, emotions and behavioural intentions: Application of an extended Mehrabian-Russell model to restaurants. Journal of Business Research, 62(4), 451460.

Lee, J. 2013. Hospital food service moving new directions [online]. Retrieved from: http: //www.modernhealthcare.com/ article/20130427/MAGAZINE/301049827

Lee, S. R. M. \& Kim, E. K. 2017. The Effects of Korean Medical Service Quality and Satisfaction on Revisit Intention of the United Arab Emirates Government Sponsored Patients. Korean Society of Nursing Science, 11, 142-149.

Mishra, P.H. \& Gupta S. 2012. Study of patient satisfaction in a surgical unit

of a tertiary care teaching hospital. Journal of Clinical Orthopaedics and Trauma (3), 4347. Retrieved online on December 25, 2018 at https://doi.org/10.1016/j. jcot.2012.04.002

Statista. 2018. Number of public and private hospitals in Malaysia from 2012 to 2016 [online]. Retrived from: https://statista. com/statistics/794860/number-of-publicand-private-hospitals-Malaysia/\#0

Zahid, (2015). Survey of Patients' Perception of Hospital Food Services at AFIC - NIHD Rawalpindi. Armed Forces Institute of Cardiology/ National Institute of Heart Diseases Rawalpindi. 
